\title{
Technetium Tc 99m Trofolastat
}

National Cancer Institute

\section{Source}

National Cancer Institute. Technetium Tc 99m Trofolastat. NCI Thesaurus. Code

C116887.

A radioconjug ate composed of an urea-based human prostate-specific membrane antigen (PSMA)-targeting ligand, conjugated to the gamma-emitting radioisotope technetium Tc 99m, with potential use as a tracer for PSMA-expressing tumors using single photon emission computed tomography/computed tomography (SPECT/CT). Upon intravenous administration of the technetium Tc 99m trofolastat, the trofolastat moiety targets and binds to PSMA-expressing tumor cells. Upon internalization, PSMAexpressing tumor cells can be detected during SPECT/CT imaging. PSMA, a tumorassociated antigen and type II transmembrane protein, is expressed on the membrane of prostatic epithelial cells and overexpressed on prostate tumor cells. 